\title{
Sustained Change in ADHD: Interventions and Variables That Lead to Durable Improvements in Symptoms and Quality of Life
}

\author{
Trinidad García *(1) and Celestino Rodríguez (1) \\ Department of Psychology, University of Oviedo, 33003 Oviedo, Spain; rodriguezcelestino@uniovi.es \\ * Correspondence: garciatrinidad@uniovi.es
}

Citation: García, T.; Rodríguez, C. Sustained Change in ADHD: Interventions and Variables That Lead to Durable Improvements in Symptoms and Quality of Life. Sustainability 2021, 13, 13721. https: / / doi.org/10.3390/ su132413721

Received: 30 November 2021 Accepted: 9 December 2021 Published: 13 December 2021

Publisher's Note: MDPI stays neutral with regard to jurisdictional claims in published maps and institutional affiliations.

Copyright: (c) 2021 by the authors. Licensee MDPI, Basel, Switzerland. This article is an open access article distributed under the terms and conditions of the Creative Commons Attribution (CC BY) license (https:// creativecommons.org/licenses/by/ $4.0 /)$.
Attention Deficit/Hyperactivity Disorder (ADHD) is one of the most common conditions in childhood, but it also persists into adolescence and adulthood, showing prevalence rates from $5.3 \%(95 \% \mathrm{CI}=5.0,5.6)([1]$ to $7.2 \%(95 \% \mathrm{CI}=6.7,7.8)[2]$ in children and adolescents, and $2.5 \%(95 \% \mathrm{CI}=2.1,3.1)$ in adults across the world $[3,4]$. It is characterized as a persistent pattern of inattention, hyperactivity and/or impulsivity [5], which deals with the following three main presentations of the disorder: inattentive presentation, hyperactive/impulsive presentations and combined presentation.

This disorder commonly causes a significant impairment in important areas of daily life, such as family, school, the workplace and social relationships [6-8], also affecting life satisfaction [9-11]. More specifically, [9] examined impairment and symptoms of ADHD in children and adolescents from six European countries, based on the information provided by parents/caregivers of children/adolescents with $\operatorname{ADHD}(n=535)$ and without ADHD $(n=424)$. The results indicated that the ADHD group showed significantly higher levels of school impairment compared with the control group, while they were also more likely to be in the bottom of their class. These results are coherent with other recent studies, indicating that school (and family) might be the most affected context in children and adolescents with ADHD $[10,12,13]$. In the case of adults, ref. [11] found that ADHD symptoms correlated negatively with life satisfaction, even after demographic factors, such as gender, age or income, and common risk factors (e.g., not being in a relationship, being unemployed) were controlled for.

While ADHD is one of the most frequently diagnosed disorders in childhood, which implies that multiple valid and relievable assessment processes and techniques are systematically being used, the effectiveness of interventions aimed to reduce and or prevent the chronification of some core symptoms of ADHD and associated difficulties is, sometimes, under debate [14]. In this sense, not just variables related to the intervention but also with the individual and their context (either closer contexts, such as family and community factors, or more external variables, such as advances in clinical and education research and practice in the last few years or current events of our society, i.e., COVID-19 confinement) are relevant aspects to consider in order to determine the effectiveness of such interventions, which aim not just to temporarily deal with the main symptoms of the disorder, but to produce a sustained change, an improvement, in the symptoms and quality of life of people with ADHD.

This Special Issue had the following two aims: first, to provide a scenario for presenting and discussing current advances in intervention procedures, from traditional approaches to new techniques, from the perspective of their effectiveness and the durability of their effects; and second, to invite authors to present their findings on the role of personal and contextual variables on the effectiveness of such interventions and the progression of the disorder across the lifespan.

The six articles in this Special Issue are from researchers coming from Iran, Germany, Norway, Spain, the UK, Sweden, Norway and the Netherlands. Five of them are empirical 
studies and imply a total sample of 1216 children and adolescents (aged 6 to 18), and 230 adults (aged 19 to 49), including ADHD, SCT (Sluggish Cognitive Tempo) and nonADHD clinical or normative samples. The last article is a literature review based on the analysis of 202 articles published in journals under the Social Sciences Citation Index from 2015 to 2019.

Three of the six articles deal with variables around ADHD characteristics, including family (parental mood disorders and laxness, parenting stress, coherence), personal (oppositionist behavior, executive function deficits, cognitive deficits, anxiety) and contextual variables (confinement related to COVID-19) [15-17]. They use descriptive, predictive and comparative data analyses. One article shows the effects of an intervention based on perceptual-motor skills' reconstruction to improve the executive functions and key symptoms in ADHD, based on a sample of 50 students (8-10 years) equally distributed in a control and an experimental group, following a pretest-posttest design [18]. Additionally, this Special Issue includes a follow-up study based on a 12-year time lapse, where the main aim is to examine the role of family and behavioral and neuropsychological factors when predicting long-term functional outcomes in young adults with ADHD [19]. Last but not least, the bibliometric review that closes this Special Issue provides evidence on the communication gap that still exists between the scientific fields of Psychiatry/Psychology and Education concerning classroom management of ADHD, that is, between science and practice [20].

Overall, five of the six articles highlight the role of an important variable considering the characterization of and intervention in ADHD, which is executive functions, defined as a set of cognitive processes that allow the control of thought, behavior and affection according to the achievement of a goal [21]. These variables, such as inhibitory control, working memory, cognitive flexibility or planning, have been demonstrated to have an important role in predicting current symptoms of ADHD, distinguishing ADHD from other disorders such as SCT, predicting long-term functional involvement, as well as being important factors to incorporate as part of ADHD interventions, based both on the evidence provided in this Special Issue and also in the previous literature [22-25]. This again supports the importance of these components in the identification, interventions and follow-up processes that characterize the current clinical and educational practice in ADHD. Finally, as most of the articles that are part of this Special Issue suggest, and [20] corroborate in their review, future research addressing the personal and contextual variables involved in ADHD characterization and intervention is still needed, hoping that research provides new directions to promote educational and clinical resources to achieve a sustained change and improvement in ADHD symptoms and the quality of life of this population.

Author Contributions: Conceptualization, T.G. and C.R.; methodology, T.G.; resources, C.R.; writing —original draft preparation, T.G. and C.R.; writing-review and editing, T.G. and C.R.; funding acquisition, C.R. All authors have read and agreed to the published version of the manuscript.

Data Availability Statement: Not applicable.

Acknowledgments: This work has been supported by two projects from the Spanish Ministry of Economy and Industry (Ref. MCIU-19-PGC2018-097739-B-I00 and Ref. MCI-20-PID2019-107201GBI00). We also acknowledge the authors and participants from the six articles cited, whose cooperation has helped meeting the main objective of this Special Issue, that is, serving as a meeting and discussion place for current research on ADHD, its intervention and associated variables.

Conflicts of Interest: The authors declare no conflict of interest.

\section{References}

1. Polanczyk, G.; De Lima, M.S.; Horta, B.L.; Biederman, J.; Rohde, L.A. The worldwide prevalence of ADHD: A systematic review and metaregression analysis. Am. J. Psychiatry 2007, 164, 942-948. [CrossRef] [PubMed]

2. Thomas, R.; Sanders, S.; Doust, J.; Beller, E.; Glasziou, P. Prevalence of attention-deficit/hyperactivity disorder: A systematic review and meta-analysis. Pediatrics 2015, 135, e994-e1001. [CrossRef] [PubMed] 
3. Simon, V.; Czobor, P.; Balint, S.; Meszaros, A.; Bitter, I. Prevalence and correlates of adult attention-deficit hyperactivity disorder: Meta-analysis. Br. J. Psychiatry 2009, 194, 204-211. [CrossRef] [PubMed]

4. Dobrosavljevic, M.; Solares, C.; Cortese, S.; Andershed, H.; Larsson, H. Prevalence of attention-deficit/hyperactivity disorder in older adults: A systematic review and meta-analysis. Neurosci. Biobehav. Rev. 2020, 118, 282-289. [CrossRef] [PubMed]

5. American Psychiatric Association. Diagnostic and Statistical Manual of Mental Disorders: DSM-5, 5th ed.; American Psychiatric Association: Washington, DC, USA, 2013.

6. Colomer, C.; Berenguer, C.; Roselló, B.; Baixauli, I.; Miranda, A. The Impact of Inattention, Hyperactivity/Impulsivity Symptoms, and Executive Functions on Learning Behaviors of Children with ADHD. Front. Psychol. 2017, 12, 540. [CrossRef]

7. García, T.; Rodríguez, C.; Rodríguez, J.; Fernández-Suarez, A.; Richarte, V.; Ramos-Quiroga, J.A. Psychosocial profiles of adults with ADHD: A comparative study of prison and outpatient psychiatric samples. Eur. J. Psychol. Appl. Leg. Context 2019, 11, 41-49. [CrossRef]

8. Thoma, P.; Sonnenburg, S.; Marcinkowski, N.; Juckel, G.; Edel, M.A.; Suchan, B. Social problem solving in adult patients with attention deficit hyperactivity disorder. Psychiatry Res. 2020, 285, 112721. [CrossRef]

9. Caci, H.; Doepfner, M.; Asherson, P.; Donfrancesco, R.; Faraone, S.V.; Hervas, A.; Fitzgerald, M. Daily life impairments associated with self-reported childhood/adolescent attention-deficit/hyperactivity disorder and experiences of diagnosis and treatment: Results from the European Lifetime Impairment Survey. Eur. Psychiatry 2014, 29, 316-323. [CrossRef] [PubMed]

10. García, T.; Fernández, E.; Villalba, M.; Areces, D.; Rodríguez, C. What Predicts Life Satisfaction in Children and Adolescents with Attention-Deficit/Hyperactivity Disorder (ADHD)? A Study from Parent and Child/Adolescent Perspectives. Span. J. Psychol. 2021, 22, e12. [CrossRef]

11. Hennig, T.; Koglin, U.; Schmidt, S.; Petermann, F.; Brähler, E. Attention-Deficit/Hyperactivity Disorder Symptoms and Life Satisfaction in a Representative Adolescent and Adult Sample. J. Nerv. Ment. Dis. 2017, 205, 720-724. [CrossRef]

12. Barfield, P.A. Life satisfaction in children with attention deficit hyperactivity disorder: Looking beyond proxy reports. J. Child. Adolesc. Psychiatr. Nurs. 2018, 31, 102-108. [CrossRef] [PubMed]

13. Ogg, J.A.; Bateman, L.; Dedrick, R.F.; Suldo, M. The relationship between life satisfaction and ADHD symptoms in middle school students: Using a bifactor model. J. Atten. Disord. 2016, 20, 390-399. [CrossRef] [PubMed]

14. Thapar, A.; Langley, K.; Muñoz-Solomando, A. The ADHD debate: Being mindful of complexity and wary of reductionist explanations and polarization: Commentary on 'A social relational critique of the biomedical definition and treatment of ADHD; ethical, practical and political implications'. J. Fam. Ther. 2013, 35, 219-223. [CrossRef]

15. Collado-Valero, J.; Navarro-Soria, I.; Delgado-Domenech, B.; Real-Fernández, M.; Costa-López, B.; Mazón-Esquiva, I.; LavigneCerván, R. ADHD and Sluggish Cognitive Tempo: Comparing Executive Functioning Response Patterns. Sustainability 2021, 13, 10506. [CrossRef]

16. Guo, N.; Fuermaier, A.B.M.; Koerts, J.; Mueller, B.W.; Mette, C.; Tucha, L.; Scherbaum, N.; Tucha, O. The Role of Self- and Informant-Reports on Symptoms and Impairments in the Clinical Evaluation of Adult ADHD. Sustainability 2021, $13,4564$. [CrossRef]

17. Navarro-Soria, I.; Real-Fernández, M.; Juárez-Ruiz de Mier, R.; Costa-López, B.; Sánchez, M.; Lavigne, R. Consequences of Confinement Due to COVID-19 in Spain on Anxiety, Sleep and Executive Functioning of Children and Adolescents with ADHD. Sustainability 2021, 13, 2487. [CrossRef]

18. Soltani-Kouhbanani, S.; Rothenberge, A. Perceptual-Motor Skills Reconstruction Program Improves Executive Functions in Children with Attention-Deficit/Hyperactivity Disorder. Sustainability 2021, 13, 6210. [CrossRef]

19. Miranda, A.; Berenguer, C.; Roselló, B.; Martínez-Raga, J.; Mulas, F. Contribution of Family, Behavioral, and Neuropsychological Factors to Long-Term Functional Outcomes in Young Adults with ADHD: A 12-Year Follow-Up Study. Sustainability 2021, 13, 814. [CrossRef]

20. Dort, M.; Strelow, A.E.; French, B.; Groom, M.; Luman, M.; Thorell, L.B.; Biele, G.; Christiansen, H. Bibliometric Review: Classroom Management in ADHD-Is There a Communication Gap Concerning Knowledge Between the Scientific Fields Psychiatry/Psychology and Education? Sustainability 2020, 12, 6826. [CrossRef]

21. Zelazo, P.D.; Carlson, S. Hot and Cool Executive Function in Childhood and Adolescence: Development and Plasticity. Child. Dev. Perspect. 2012, 6, 354-360. [CrossRef]

22. Dovis, S.; Van der Oord, S.; Wiers, R.W.; Prins, P.J. Improving executive functioning in children with ADHD: Training multiple executive functions within the context of a computer game. a randomized double-blind placebo controlled trial. PLoS ONE 2015, 10, e0121651. [CrossRef] [PubMed]

23. Kray, J.; Ferdinand, N.K. How to Improve Cognitive Control in Development During Childhood: Potentials and Limits of Cognitive Interventions. Child. Dev. Perspect. 2013, 7, 121-125. [CrossRef]

24. Thorell, L.B.; Veleiro, A.; Siu, A.F.; Mohammadi, H. Examining the relation between ratings of executive functioning and academic achievement: Findings from a cross-cultural study. Child. Neuropsychol. 2012, 19, 630-638. [CrossRef] [PubMed]

25. Zhao, X.; Chen, L.; Maes, J.H. Training and transfer effects of response inhibition training in children and adults. Dev. Sci. 2018, 21, 125-131. [CrossRef] 